\title{
Basic Mining Geotechnical Training in Mining Geology Department Vocational School (SMK) Aviation Techno Makassar
}

\section{Pelatihan Basic Geoteknik Tambang Jurusan Geologi Pertambangan Sekolah Menengah Kejuruan (SMK) Penerbang Techno Terapan Kota Makassar}

\author{
Habibie Anwar* \& Abd. Salam Munir \\ Jurusan Teknik Pertambangan, Fakultas Teknologi Industri, Universitas Muslim Indonesia, Indonesia
}

\begin{abstract}
The main target of the Lembaga Pengabdian kepada Masyarakat (LPkM) UMI program for SMK Penerbang Techno Terapan is to prepare early for the ability of the students of the Mining Geology Department to be able to starter Mining Geotechnics before entering the world of work, this is related to the Geology and Mining fields in the learning process teaching in high schools. The problems experienced by partners are limitations in knowledge regarding Mining Geotechnics, especially in open mines and underground mines, with this training, it can indirectly teach students to interpret Geotechnical data in the field and assist in working neatly, planned and effective every time, so that the expected result is to facilitate knowledge and improve the quality of students in learning Mining Geotechnical training.
\end{abstract}

\begin{abstract}
Abstrak
Program Lembaga Pengabdian kepada Masyarakat (LPkM) UMI kepada mitra SMK Penerbang Techno Terapan Makassar adalah mempersiapkan secara dini kemampuan para taruna-taruni Jurusan Geologi Pertambangan agar dapat menguasai Geoteknik Tambang sebelum memasuki dunia kerja, hal ini terkait dengan bidang Geologi dan Pertambangan dalam proses belajar mengajar di sekolah. Permasalahan yang dialami oleh mitra yaitu keterbatasan dalam ilmu pengetahuan berkenaan Geoteknik Tambang terutama pada tambang terbuka dan tambang bawah tanah, dengan adanya pelatihan ini, secara tidak langsung dapat mengajarkan kepada taruna-taruni untuk menginterpretasikan data Geoteknik yang ada dilapangan dan membantu dalam bekerja secara rapi, terencana dan efektif setiap waktu, sehingga hasil yang diharapkan adalah memperlancar ilmu pengetahuan dan peningkatan kualitas para taruna-taruni dalam mempelajari dan menguasai pelatihan Geoteknik Tambang.
\end{abstract}

(C) 2021 Author(s)

Keywords: geology, mining, geotechnic, lpkm, training

\section{Pendahuluan}

Perkembangan informasi memungkinkan kemudahan dalam melakukan kegiatan pelatihan Geoteknik Tambang karena bisa dilakukan didalam sekolah, diluar sekolah dan dimana saja. Sistem informasi yang diberikan ini juga sangat mendukung interaksi antara guru dan siswa dalam proses belajar mengajar khususnya mata pelajaran yang terkait dengan kejuruan seperti Geologi Dasar, Pemetaan Geologi dan geoteknik tambang.

\footnotetext{
* Corresponding author:

E-mail address: hbbnwr@umi.ac.id (Habibie Anwar)
} 
Pada pelatihan geoteknik ini sangat penting dalam dunia pertambangan karena aktivitas penggalian pada tambang terbuka mineral dan batubara akan selalu menghadapi permasalahan kestabilan lereng (Arif, 2016). Dengan adanya pelatihan ini, akan memberikan ilmu wawasan baru bagi taruna-taruni dalam menginterpretasikan data Geoteknik setelah menamatkan Pendidikannya di sekolah.

Kegiatan pelatihan Geoteknik Tambang juga akan mengalihkan perhatian taruna-taruni untuk lebih aktif lagi belajar dan mempraktekkannya, maka dengan sendirinya akan menghindari atau mengurangi kejadian kriminal anak remaja dan diluar sekolah pada jam sekolah yang merupakan bentuk kenakalan remaja yang dilakukan karena kurangnya kontrol dan pengawasan yang dilakukan oleh pihak sekolah terhadap anak didiknya pada saat jam belajar.

Sekolah sebagai tempat belajar mengajar merupakan tempat untuk menyalurkan ilmu pengetahuan dan informasi, kegiatan guru dan taruna-taruni di sekolah dapat lebih interaktif sehingga guru lebih maksimal dalam melakukan proses belajar mengajar, Oleh karena itu Lembaga pengabdian kepada masyarakat (LPkM) UMI bermaksud untuk mengadakan pelatihan Geoteknik di SMK Penerbang Techno Terapan Makassar.

\section{Masalah}

Berdasarkan analisis kondisi mitra sekolah terdapat beberapa permasalahan yang muncul yaitu pihak taruna-taruni di SMK Penerbang Techno Terapan jurusan Geologi Pertambangan memiliki keterbatasan pengetahuan berkenaan dengan Geoteknik Tambang seperti metode longsoran (Hoek \& Bray, 1981), metode rock mass rating (RMR) untuk mengetahui kualitas suatu massa batuan (Bieniawski, 1989), metode rock quality designation (RQD) untuk menilai mutu dan kualitas suatu batuan (Deere, 1964), format data survey scanline merujuk pada (Wyllie and Mah, 2004) dan klasifikasi slope mass rating (Romana, 1993)

Untuk memberikan solusi terkait dengan masalah Geoteknik tambang maka LPkM UMI mengadakan kegiatan pelatihan Geoteknik Tambang, sehingga mitra sekolah akan mudah memahami, merancang dan menginterpretasikan data-data geoteknik yang ada dilapangan.

\section{Target dan Luaran}

Target utama pada program LPkM UMI ini adalah mempersiapkan secara dini kemampuan taruna-taruni agar dapat menguasai Geoteknik Tambang sebelum memasuki dunia kerja yang terkait dengan bidang geologi dan pertambangan. Dengan kemampuan dan penguasaan Geoteknik ini, siswa diharapkan nantinya lebih mudah dan cepat bersinergi dengan dunia kerja karena saat ini hampir semua perusahaan tambang telah menggunakan metode Geoteknik pada tambang terbuka dan tambang bawah tanah (underground) khususnya dalam perencanaan, pelaksanaan maupun evaluasi perkembangan tambang.

Luaran yang diharapkan adalah peningkatan kualitas layanan mitra sekolah dengan sistem ini akan mempermudah taruna-taruni SMK jurusan geologi pertambangan dalam mempelajari dan menguasai Geoteknik Tambang.

\section{Metode}

Untuk menyikapi pandemi covid19 di tahun 2020 ini maka proses belajar yang sebelumnya akan dilaksanakan secara tatap muka (offline), diganti dengan pembelajaran secara daring menggunakan aplikasi zoom, pada pelatihan secara online ini tidak mengurangi kualitas dari pelatihan itu sendiri. Adapun dan metode pelaksanaan yang ditawarkan dalam pelatihan Geoteknik Tambang ini adalah memberikan materi tentang Geoteknik pada tambang terbuka dan Geoteknik pada tambang bawah tanah.

Pelatihan basic Geoteknik Tambang bagi taruna-taruni SMK Penerbang Techno Terapan Makassar dilaksanakan selama 2 hari yaitu pada tanggal 12 dan 22 oktober 2020. kegiatan pelatihan berjalan dengan lancar dihadiri oleh 29 peserta dari 40 undangan. Para peserta pelatihan terlihat antusias dengan materi pelatihan yang diberikan. Hal ini terlihat dari awal hingga akhir acara, semua peserta mengikuti dengan baik. Pada hari pertama tanggal 12 oktober materi yang diberikan yaitu geoteknik tambang terbuka, dimana pada materi tersebut meliputi penyelidikan, 
pengolahan data geoteknik serta pemantauan kestabilan lereng. Pada hari selanjutnya yaitu pada tanggal 22 oktober 2020 kembali memberikan materi yaitu geoteknik tambang bawah tanah.

Pada proses pelatihan Geoteknik Tambang berlangsung, selanjutnya pada sesi tanya jawab dan diskusi antara peserta pelatihan dan dosen pengabdi untuk meningkatkan pemahaman sehingga akan memperoleh hasil yang diinginkan. Berdasarkan hasil kegiatan dapat diidentifikasi mengenai tingkat pemahaman peserta pengabdian adalah bahwa $65 \%$ peserta pengabdian memahami konsep pelatihan geoteknik tambang, arti penting pada pelatihan ini yaitu pengetahuan pada kondisi lapangan diperusahaan tambang dan peningkatan kualitas dan kuantitas pada pelaporan berupa hasil pengolahan data-data geoteknik yang digunakan dan selanjutnya memberikan rekomendasi keteknikan berdasarkan hasil geoteknik yang telah diolah.

\section{Hasil dan Pembahasan}

Kegiatan pelatihan basic Geoteknik tambang memang nyata-nyata dibutuhkan bagi taruna-taruni SMK Penerbang Techno Terapan jurusan geologi pertambangan. Kebanyakan para peserta yang mengikuti kegiatan ini sangat terbatas pengetahuan dan pemahaman akan ilmu geoteknik tambang dan Taruna-taruni menyadari sepenuhnya, bahwa geoteknik tambang penting bagi mereka sebagai bentuk keahlian yang sangat dibutuhkan saat ini. Oleh karena itu, para taruna dan taruni merasakan dampak manfaat yang telah diperoleh dari pelatihan ini untuk meningkatkan kemampuannya dalam hal Geoteknik Tambang.

Para taruna-taruni juga dapat mengembangkan ilmu yang telah diberikan pada pelatihan ini, agar ilmu yang diembannya selanjutnya dapat dikembangkan dan tidak tertinggal. Agar pada pelatihan ini bermanfaat bagi tarunataruni, maka sebaiknya dipraktikumkan atau membuat kelompok keahlian dibidang geoteknik tambang, agar pelatihan ini memberikan manfaat bagi generasi-generasi selanjutnya di SMK Penerbang Techno Terapan Makassar.

Berdasarkan hasil pengamatan, ada dua faktor yang berkaitan dengan pelaksanaan kegiatan Pelatihan Geoteknik yaitu:

\section{Faktor Pendukung}

Hal-hal yang mendukung berjalannya kegiatan pengabdian ini dapat diidentifikasi diantaranya antusisme para peserta pelatihan.

\section{Faktor Penghambat}

Lancarnya pelaksanaan kegiatan pengabdian bukan berarti tanpa hambatan. Selama pengabdian ada beberapa hal yang diidentifikasi sebagai faktor penghambat kegiatan pengabdian diantaranya adalah rendahnya kemauan untuk meningkatkan kualitas dan pengembangan diri selama pelatihan.

\section{Kesimpulan}

Pada pelatihan geoteknik tambang untuk para taruna-taruni dapat berjalan dengan lancar. Hampir semua peserta antusias dan merasakan manfaat pelatihan. Pelaksanaan pengabdian untuk taruna taruni SMK penerbang Techno Terapan Makassar jurusan Geologi Pertambangan dapat disimpulkan berhasil melakukan kegiatan pelatihan ini. Keberhasilan ini ditunjukkan antara lain oleh :

a) adanya kesesuaian materi yang dibutuhkan taruna-taruni untuk meningkatkan keilmuan secara profesionalitasnya

b) adanya respon yang positif dari taruna-taruni mengingat kegiatan pengabdian merupakan kebutuhan para siswa dalam rangka meningkatkan keilmuannya

c) sebagian besar (65\%) taruna-taruni telah memahami konsep dari pelatihan ini 


\section{Saran}

untuk meningkatkan kemampuan dalam hal Geoteknik Tambang maka saran yang diberikan adalah para taruna-taruni dapat mengembangkan kreatifitasnya dengan cara membuat forum diskusi atau kelompok belajar agar pemahaman selanjutnya bisa dimengerti oleh tiap generasi dan selanjutnya para taruna-taruni meminta agar pelatihan serupa dapat dilaksanakan kembali dengan peserta (audience) yang lebih banyak.

\section{Acknowledgements}

Terima kasih kepada Kepala Sekolah, Guru dan Taruna-taruni SMK Penerbang Techno Terapan Makassar Jurusan Geologi Pertambangan atas dukungan serta kerja sama hingga pengabdian masyarakat ini dapat terlaksana dengan baik.

\section{References}

Arif, I. I. (2016). Geoteknik Tambang. Gramedia Pustaka Utama.

Bieniawski, Z. T. (1989). Engineering rock mass classifications: a complete manual for engineers and geologists in mining, civil, and petroleum engineering. John Wiley \& Sons.

Deere, D. U. (1964). Technical description of rock cores for engineering purpose. Rock Mechanics and Enginee-ring Geology, 1(1), 17-22.

Hoek, E., \& Bray, J. D. (1981). Rock slope engineering. CRC Press.

Romana, M. R. (1993). A geomechanical classification for slopes: slope mass rating. In Rock testing and site characterization (pp. 575-600). Pergamon.

Wylie, D. C., \& Mah, C. W. (2004). Rock slope engineering. Civil and Mining. 